URBAN LATIN AMERICA 
The Texas Pan American Series 


\section{Urban Latin America}

The Political Condition from

Above and Below

by Alejandro Portes and

John Walton

$\overline{\mathrm{QP}}$

University of Texas Press

Austin 
The Texas Pan American Series is published with the assistance of a revolving publication fund established by the Pan American Sulphur Company.

Library of Congress Cataloging in Publication Data

Portes, Alejandro, 1944-

Urban Latin America.

(Texas pan-American series]

Bibliography: p.

Includes index.

1. Cities and towns-Latin America. 2. Poor-Latin America.

3. Power (Social Sciences) I. Walton, John, 1937- joint author.

II. Title.

HT127.5.P67 301.36'3'098 75-23171

ISBN 0-292-76427-8

Copyright (C) 1976 by Alejandro Portes and John Walton

All rights reserved

Printed in the United States of America 